\title{
Poor dietary quality of complementary foods is associated with multiple micronutrient deficiencies during early childhood in Mongolia
}

\author{
$\mathrm{R}_{\text {Lander }}{ }^{1}$, TS Enkhjargal ${ }^{2}$, J Batjargal ${ }^{2}, \mathrm{~N} \mathrm{Bolormaa}^{2}$, D Enkhmyagmar ${ }^{2}$, \\ U Tserendolgor ${ }^{2}$, S Tungalag ${ }^{2}$, K Bailey $^{1}$ and RS Gibson ${ }^{1, *}$ \\ 'Department of Human Nutrition, University of Otago, Union Street, PO Box 56, Dunedin 9015, New Zealand: \\ ${ }^{2}$ Public Health Institute, Ulaanbaatar, Mongolia
}

Submitted 7 April 2009: Accepted 23 September 2009: First published online 28 0ctober 2009

\begin{abstract}
Objective: To assess whether persistent micronutrient deficiencies in Mongolian children identified in our earlier biochemical study are associated with inadequacies in quantity and/or quality in their complementary diets.

Design: A cross-sectional study of breast-fed children aged 6-23 months, randomly selected from four districts in Ulaanbaatar and four provincial capitals.

Subjects: Weight and length were measured, and sociodemographic status, feeding practices and nutrient adequacy of complementary foods for children aged 6-8 months ( $n$ 26), 9-11 months ( $n$ 29) and 12-23 months ( $n$ 73) were assessed via questionnaire and in-home interactive $24 \mathrm{~h}$ recalls.

Results: No geographic differences existed so data were combined. Adherence to WHO infant and young child feeding practices was poor: few children were exclusively breast-fed up to 6 months of age or received the recommended number of feedings containing the recommended number of food groups. Nevertheless, energy intakes from complementary diets, primarily from cereals and non-nutritious snacks, were above WHO-estimated needs; $<1 \%$ of energy was from meat and eggs or fruits and vegetables. Median intakes and densities of most nutrients (except protein, thiamin and riboflavin) failed to meet WHO recommendations for at least two age groups, assuming average breast milk intake; greatest density deficits were for $\mathrm{Fe}>$ vitamin $\mathrm{C}>$ vitamin $\mathrm{A}>\mathrm{Zn}>\mathrm{Ca}$. Conclusions: Complementary feeding in Mongolia is compromised by deficits in several micronutrients but not energy, in part because of frequent consumption of non-nutritious snacks. The latter may interfere with breast-feeding and should be avoided. Instead, wheat-based complementary foods should be enriched with affordable cellular animal foods and fruits rich in vitamin $\mathrm{C}$ to combat existing micronutrient deficits.
\end{abstract}

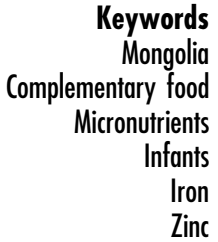

In many disadvantaged countries, nutritionally adequate complementary foods that can be safely introduced after 6 months of age do not exist, especially for mothers living in resource-poor households ${ }^{(1)}$. Instead, complementary foods in these countries are frequently based almost exclusively on cereals, despite the evidence that such foods are often accompanied by major deficits in $\mathrm{Fe}, \mathrm{Zn}$, Ca and vitamin $\mathrm{A}^{(2-5)}$. Indeed, the large discrepancy between the content of these four micronutrients in complementary foods and the amount required by the breast-fed infant has led $\mathrm{WHO}^{(3)}$ to define these as problem micronutrients. The mineral deficits are due in part to the high content of phytic acid (myoinositol hexaphosphate) in cereals, a potent inhibitor of mineral absorption ${ }^{(3,6)}$.

Mongolia, unlike most disadvantaged countries, is distinguished by a cultural heritage of a meat-based diet.
There are well-established benefits of including animalsource foods when feeding infants and young children ${ }^{(7-9)}$. Indeed, these benefits have led the Pan American Health Organization (PAHO)/ $\mathrm{WHO}^{(1)}$ in their complementary feeding guidelines for the breast-fed child to specify that meat, poultry, fish or eggs should be consumed daily, or as often as possible. Nevertheless, the complementary foods presently consumed throughout Mongolia rarely contain meat and instead are based almost exclusively on cereals, predominantly wheat flour and rice. Hence, it is likely that deficits in the four problem micronutrients exist in complementary diets in Mongolia and may be partly responsible for the micronutrient deficiencies which persist throughout early childhood ${ }^{(10,11)}$.

Recent national surveys in Mongolia ${ }^{(10,12)}$ indicate that breast-feeding is almost universal and generally practised 
up to 2 years of age. Further, few mothers practise active feeding, but instead feed their children a very restricted range of foods only when they are hungry ${ }^{(13)}$. However, the extent to which the Mongolian complementary diets are inadequate in quantity, quality, or both, is uncertain because of the paucity of quantitative data on energy and nutrient intakes from Mongolian complementary foods. Consequently, in the current cross-sectional study, our objectives were to: (i) quantify the complementary feeding practices of breast-fed Mongolian children aged 6 to 23 months; (ii) calculate the energy and nutrient intakes from complementary foods; and (iii) evaluate their adequacy by comparison with the WHO recommendations. Such information is essential for developing strategies to enhance the quality of complementary feeding in Mongolia during the vulnerable period of transition from breast-feeding to the family diet.

\section{Subjects and methods}

\section{Subjects}

The subjects of the present study were all the breast-fed children ( $n$ 130) aged 6 to 23.99 months who were participants of a larger cross-sectional micronutrient survey ${ }^{(11)}$. The children were recruited from four districts in Ulaanbaatar, the capital city of Mongolia, and four provincial capitals of Bulgan, Bayanhongor, Dornod and Khovd, located in the northern, southern, eastern and western parts of Mongolia. Eligible children were identified through official lists prepared by the local district governor's office in collaboration with district hospitals. Inclusion criteria were apparently healthy children aged 6 to 36 months with no evidence of infection within the previous $7 \mathrm{~d}$, and whose primary caregivers were willing to allow them to participate. Eligible children were stratified by age and sex, and every fourth child randomly selected from a randomized list of each stratum. To minimize correlation between participants, only one child per family was selected. Our data and sample size allowed us to characterize the mean energy intake of each age group with a $95 \%$ confidence interval of approximately $\pm 588 \mathrm{~kJ}$.

Written informed consent was obtained from the parents or guardians of the children, and the study protocol was approved by the Human Ethics Committee of the Mongolian Ministry of Health. The dietary data reported here were collected in November 2006, at the same time as the biochemical data ${ }^{(11)}$.

\section{Methods}

Assessment of sociodemographic, bealth and anthropometric status

Details of the questionnaire used to assess the sociodemographic, health and breast-feeding status of the children, and the anthropometric methods, have been reported elsewhere ${ }^{(11)}$. Mean anthropometric $Z$-scores for weight-for-age (WAZ), length-for-age (LAZ), weight-forlength (WLZ) and BMI (BMIZ) were calculated for three age groups: 6 to 8.99 months (Grp-1, $n$ 26), 9 to 11.99 months (Grp-2, $n$ 29) and 12 to 23.99 months (Grp-3, n 73), based on the WHO 2007 multicentre growth reference data using the computer program WHO Anthro $2005^{(14)}$. None of the children had unacceptably extreme anthropometric values ${ }^{(15)}$.

Assessment of feeding practices and food intakes from complementary foods

Trained research assistants conducted single $24 \mathrm{~h}$ recalls with the caregiver of each child using the interactive, multiple-pass technique validated earlier ${ }^{(16)}$; all days of the week were represented in the final sample. The assessment period lasted from the time the children awoke until they were put to bed for the night. Interviews were conducted in the participant's homes to encourage participation, improve the recall of foods consumed, and permit the calibration of family utensils. Information on breast-feeding practices and the age of introduction of other liquids (including water, water-based drinks or solids), based on self-reports by the mothers, was also collected during the recall interviews.

For actual portions of cooked foods consumed by the child, including wheat-based porridges, caregivers were requested to spoon the portions consumed by the child into the child's bowl, which was then weighed on dietary scales (Soehnle; CMS Weighing Equipment, London, UK). For composite dishes, household recipe data were collected.

From the food intake data, the mean number of times children were fed solid/semi-solid foods and mean number of food groups consumed over the $24 \mathrm{~h}$ recall period were calculated, from which three indicators related to optimal infant and young child feeding (IYCF) practices were compiled $^{(1)}$, as specified by Arimond and Ruel ${ }^{(17)}$. The indicators were: (i) percentage fed solid/semi-solid foods the recommended minimum number of times or more (i.e. $\geq 2$ times/d for Grp-1 and $\geq 3$ times/d for Grp-2 and Grp-3); (ii) percentage fed the minimum number of food groups (i.e. three) or more; and (iii) percentage fed according to good IYCF practices. The latter are defined as exclusive breast-feeding for the first 5 months, followed by the introduction of solids/semi-solids for the minimum number of times or more and including the minimum number of food groups, along with continued breast-feeding ${ }^{(1)}$. Median dietary diversity scores and the proportion classified with low (0-2), medium (3-4) and high (5-7) scores were also calculated for each age group ${ }^{(18)}$.

Assessment of intakes and major food sources of energy and nutrients from complementary foods, and their nutrient adequacy

To calculate energy and nutrient intakes from the food intake data, a unique Mongolian nutrient composition 
database containing 141 food and beverage items was compiled by R.L. using procedures outlined in Gibson and Ferguson ${ }^{(16)}$. Nutrient values were derived from an existing Mongolian food composition table and the US Department of Agriculture (USDA) National Nutrient Database for Standard Reference ${ }^{(19)}$, augmented, where necessary, with nutrient values for cooked foods, when available, from Thailand ${ }^{(20)}$, Malaysia ${ }^{(21)}$, the Philippines $^{(22)}$ and Indonesia ${ }^{(23)}$. Exceptions were the Fe, Zn, $\mathrm{Ca}$ and phytate values for the wheat flours used for the Mongolian porridges (bantan, semolina). These were based on chemical analyses of wheat flour samples purchased from vendors in the study areas in Ulaanbaatar, using methods reported earlier ${ }^{(24)}$. The nutrient composition of composite dishes was calculated from the household recipe data. When recipe data were not available from the household, data for an average recipe were substituted. Adjustments were made to all the nutrient values, where necessary, to account for differences in moisture content, and nutrient retention and yield, using factors compiled by the $\mathrm{USDA}^{(25)}$ and Banjong et l $^{(26)}$, because of the absence of Mongolian data.

Median (1st and 3rd quartile) intakes of energy and selected nutrients (per d and per $418 \mathrm{~kJ}$ (100 kcal)), phytate: $\mathrm{Zn}$ molar ratios, and sources of energy and nutrients from twelve major food groups from complementary foods, were calculated from the coded $24 \mathrm{~h}$ recalls for children of three age groups. To assess their adequacy, these median daily nutrient intakes (per $\mathrm{d}$ and per $418 \mathrm{~kJ}$ (100 kcal)) were compared with the estimated needs and desirable nutrient densities based on the WHO/FAO nutrient requirement estimates $^{(27)}$ and, for $\mathrm{Zn}$, the International Zinc Nutrition Consultative Group Recommended Dietary Allowance ${ }^{(28)}$, and calculated according to Dewey and Brown ${ }^{(29)}$. The energy requirements of male and female breast-fed infants of Grp-1 and Grp-2, expressed per kcal/kg per d as specified by FAO/WHO/United Nations University ${ }^{(30)}$, were used to calculate the estimated energy needs from complementary foods: breast-fed infants have lower energy requirements due to their lower total energy expenditure. For the children of Grp-3, the energy requirements for males and females, expressed per $\mathrm{kcal} / \mathrm{kg}$ per $\mathrm{d}$ and associated with moderate physical activity, were used ${ }^{(30)}$. An average breast milk intake and composition was assumed. Pooled data from low-income countries were used for both intakes and the concentration of vitamin A in breast milk, whereas for the other nutrients in breast milk, data were based on women in industrialized countries ${ }^{(29)}$.

\section{Statistical analyses}

All continuous variables were checked for normality using the Kolmogorov-Smirnov test. Contingency tables of selected sociodemographic and anthropometric variables, breast-feeding and complementary feeding variables by location and/or age group were tested using the $\chi^{2}$ test. Differences between sexes in the mean anthro- pometric $Z$-scores for each age group were examined using an independent sample $t$ test (equal variances not assumed). Dietary intakes (per $\mathrm{d}$ and per $418 \mathrm{~kJ}$ $(100 \mathrm{kcal}))$ of the children by the three age groups were expressed as medians (interquartile range) for consistency because of non-normal distributions for some nutrients. Differences in the median energy and nutrient intakes between Grp-1 and Grp-3 were examined using the non-parametric Kruskal-Wallis test. A $P$ value $<0.05$ indicated statistical significance. Statistical analyses were performed using the STATA statistical software package version $9 \cdot 2$ (Stata Corporation, College Station, TX, USA).

\section{Results}

\section{Sociodemographic and antbropometric status}

There were no significant differences between the breastfed children from Ulaanbaatar and the four provincial capitals for sociodemographic status and mean anthropometric $Z$-scores. The median household size was four and the median family income was about 75000 Mongolian Tugriks or \$US 65.00 per month. More than two-thirds of the fathers and mothers had at least a high school level of education. Of the children, $80 \%$ had received a vitamin A supplement within the past $200 \mathrm{~d}$, based on self-reports by the caregivers, but very few had received an Fe supplement (Table 1 ).

There were no significant differences between the mean anthropometric $Z$-scores for the males and females for each age group, with the exception of the mean LAZ for Grp-1. In this age group, the mean LAZ for males was significantly lower than that for females ( -0.55 (SD 0.67) v. 0.67 (SD 1.46); $P=0.033$ ). Mean WAZ and WLZ for the males and females combined for each age group were positive. Only the mean LAZ for the males and females combined in Grp-3 was negative. As a result, the prevalence of stunting and mild stunting (defined by LAZ $<$ $-2 \mathrm{SD}$ and $\mathrm{LAZ}<-1 \mathrm{SD}$ ) was significantly higher for Grp-3 compared with their younger counterparts. The WLZ values of all the children were positively correlated with LAZ values $(r=0 \cdot 27 ; P=0 \cdot 002)$.

\section{Feeding practices}

Feeding practices were similar for each age group of children from Ulaanbaatar and the four provincial capitals, so the data have been combined. Exclusive breastfeeding up to 6 months of age was practised by very few of the mothers with infants of Grp-1, and less than twothirds of Grp-2 and Grp-3, based on maternal self-reports during the recall interviews (Table 2).

Very few of the children, irrespective of age group, were fed solid or semi-solid foods for the recommended minimum number of times, or received the minimum number of food groups daily in addition to breast milk. Indeed, most children consumed only 0-2 food groups, 
Table 1 Selected sociodemographic data of Mongolian breast-fed children aged 6-23.99 months, and mean (SD) anthropometric Z-scores and prevalence of stunting and underweight by age group

\begin{tabular}{|c|c|c|c|c|c|c|}
\hline & & & \multicolumn{2}{|c|}{ All subjects ( $n$ 128) } & & \\
\hline & & & Median or $n / N$ & IQR or \% & & \\
\hline \multirow{8}{*}{$\begin{array}{l}\text { Median household income (\$US) } \\
\text { Median household size } \\
\text { Mothers educated } \geq \text { high school } \\
\text { Fathers educated } \geq \text { high school } \\
\text { Child given a vitamin A supplement within } 200 \mathrm{~d} \\
\text { Child given an Fe supplement within } 200 \mathrm{~d}\end{array}$} & & & 71 & 64,86 & & \\
\hline & & & 4 & 4,4 & & \\
\hline & & & $86 / 126$ & 68 & & \\
\hline & & & $74 / 99$ & 75 & & \\
\hline & & & $103 / 128$ & 80 & & \\
\hline & & & $3 / 128$ & 2 & & \\
\hline & \multicolumn{2}{|c|}{ Grp-1 (n 26) } & \multicolumn{2}{|c|}{ Grp-2 (n 29) } & \multicolumn{2}{|c|}{ Grp-3 (n 73) } \\
\hline & $n$ or Mean & $\%$ or SD & $n$ or Mean & $\%$ or SD & $n$ or Mean & $\%$ or SD \\
\hline Number and percentage of males & 10 & $38 \cdot 5$ & 16 & $55 \cdot 2$ & 43 & $58 \cdot 9$ \\
\hline Mean LAZ & 0.20 & $1 \cdot 45$ & 0.22 & 0.95 & -0.84 & $1 \cdot 04$ \\
\hline Mean WAZ & $0 \cdot 81$ & 0.97 & 0.38 & $0 \cdot 84$ & 0.44 & $1 \cdot 10$ \\
\hline Mean WLZ & 1.06 & 0.92 & 0.68 & $0 \cdot 86$ & 0.62 & 1.06 \\
\hline Mean BMIZ & 0.96 & 0.92 & 0.69 & $0 \cdot 86$ & $0 \cdot 80$ & $1 \cdot 04$ \\
\hline Prevalence of mild stunting ${ }^{*}$ & 6 & 23 & 7 & 24 & 33 & 45 \\
\hline Prevalence of stuntingt & 2 & 8 & 2 & 7 & 11 & 15 \\
\hline Prevalence of underweightł & 0 & 0 & 0 & 0 & 4 & 5 \\
\hline
\end{tabular}

IQR, interquartile range; LAZ, length-for-age Z-score; WAZ, weight-for-age Z-score; WLZ, weight-for-length Z-score; BMIZ, BMI Z-score.

*Mild stunting defined as LAZ from $-1 \cdot 0$ to $-2 \cdot 0$. Significantly different by age group $\left(P=0 \cdot 042\right.$, Pearson $\left.\chi^{2}\right)$.

tStunting defined as LAZ below $-2 \cdot 0$.

¥Underweight defined as WAZ below $-2 \cdot 0$.

Table 2 Feeding practices of Mongolian breast-fed children

\begin{tabular}{|c|c|c|c|c|c|c|}
\hline & \multicolumn{2}{|c|}{ Grp-1 (n 26) } & \multicolumn{2}{|c|}{ Grp-2 (n 29) } & \multicolumn{2}{|c|}{ Grp-3 (n 73) } \\
\hline & $n$ or Mean & $\%$ or SD & $n$ or Mean & $\%$ or SD & $n$ or Mean & $\%$ or SD \\
\hline Exclusive breast-feeding through 5.99 months & 4 & 15 & 9 & 31 & 19 & 46 \\
\hline $\begin{array}{l}\text { Consumed cereal in the last } 24 \mathrm{~h} \\
\text { Consumed dairy in the last } 24 \mathrm{~h} \\
\text { Consumed fruits in the last } 24 \mathrm{~h} \\
\text { Consumed meat/eggs in the last } 24 \mathrm{~h} \\
\text { Consumed vegetables in the last } 24 \mathrm{~h}\end{array}$ & $\begin{array}{r}24 \\
12 \\
6 \\
1 \\
4\end{array}$ & $\begin{array}{r}92 \\
46 \\
23 \\
4 \\
15\end{array}$ & $\begin{array}{r}20 \\
11 \\
5 \\
4 \\
3\end{array}$ & $\begin{array}{l}69 \\
38 \\
17 \\
14 \\
10\end{array}$ & $\begin{array}{r}51 \\
19 \\
16 \\
9 \\
11\end{array}$ & $\begin{array}{l}70 \\
26 \\
22 \\
12 \\
15\end{array}$ \\
\hline $\begin{array}{l}\text { Consumed } 0-2 \text { food groups } \\
\text { Consumed } 3-4 \text { food groups } \\
\text { Consumed } 5 \text { food groups }\end{array}$ & $\begin{array}{r}22 \\
4 \\
0\end{array}$ & $\begin{array}{r}85 \\
15 \\
0\end{array}$ & $\begin{array}{r}24 \\
5 \\
0\end{array}$ & $\begin{array}{r}83 \\
17 \\
0\end{array}$ & $\begin{array}{r}63 \\
9 \\
1\end{array}$ & $\begin{array}{r}86 \\
12 \\
1\end{array}$ \\
\hline $\begin{array}{l}\text { Mean number of food groups consumed } \\
\text { Fed solid or semi-solid foods minimum number of times or more* } \\
\text { Fed minimum number of food groups or moret } \\
\text { Fed according to IYCF practicesł } \\
\text { Consumed foods rich in vitamin A§ } \\
\text { Consumed foods rich in Fell } \\
\text { Liquid tea consumption }\end{array}$ & $\begin{array}{l}1 \cdot 81 \\
4 \\
4 \\
4 \\
4 \\
1 \\
17\end{array}$ & $\begin{array}{l}0 \cdot 85 \\
15 \\
15 \\
15 \\
15 \\
4 \\
65\end{array}$ & $\begin{array}{l}1 \cdot 48 \\
2 \\
5 \\
2 \\
4 \\
4 \\
17\end{array}$ & $\begin{array}{l}0 \cdot 99 \\
7 \\
17 \\
7 \\
14 \\
14 \\
59\end{array}$ & $\begin{array}{l}1 \cdot 45 \\
10 \\
10 \\
10 \\
9 \\
9 \\
52\end{array}$ & $\begin{array}{l}1 \cdot 00 \\
14 \\
14 \\
26 \\
12 \\
12 \\
71\end{array}$ \\
\hline
\end{tabular}

IYCF, infant and young child feeding.

*Grp-1 infants fed $\geq 2$ times/d; Grp-2 and Grp-3 subjects fed $\geq 3$ times/d.

tChildren fed three or more food groups.

¥Children 6-23 months: exclusively breastfed for 5 months, fed solids/semi-solids minimum number of times (two/three or more) and fed minimum number of food groups (three or more).

$\S$ Includes meat (and organ meat), fish, poultry, eggs, pumpkin, red or yellow yam or squash, carrots, red sweet potatoes, dark-green leafy vegetables, mango, papaya.

IIIncludes meat (including organ meat, fish, poultry and eggs).

predominantly cereals and snacks. As a result, the mean number of food groups was low, ranging from $1 \cdot 8$ for the infants of Grp-1 to 1.5 for each of the two older age groups. Foods rich in vitamin A or Fe were consumed by very few children: not more than $15 \%$ in each age group. Likewise, the proportion of children fed according to good IYCF practices itemized in Table 2 was also low, especially for the infants. Of concern was the high consumption of tea by children of all three age groups.

Major food sources and intakes of energy and selected nutrients in relation to $\mathrm{WHO}$ recommendations

Table 3 presents the food groups providing at least $15 \%$ of the energy, protein, $\mathrm{Ca}, \mathrm{Fe}, \mathrm{Zn}$ and vitamin A for the 
Table 3 Food groups contributing at least $15 \%$ of energy and selected nutrients for Mongolian breast-fed children, listed in the order of importance with the percentage contribution given in parentheses

\begin{tabular}{|c|c|c|c|}
\hline Nutrient & Grp-1 (n 26) & Grp-2 (n 29) & Grp-3 (n 73) \\
\hline Energy & $\begin{array}{l}\text { Cereals (50) } \\
\text { Snacks \& sugars (27) }\end{array}$ & $\begin{array}{l}\text { Cereals (36) } \\
\text { Snacks \& sugars (35) }\end{array}$ & $\begin{array}{l}\text { Snacks \& sugars (40) } \\
\text { Cereals }(26) \\
\text { Soups }(17)\end{array}$ \\
\hline Protein & Cereals (65) & $\begin{array}{l}\text { Cereals (41) } \\
\text { Soups (17) } \\
\text { Snacks \& sugars (17) } \\
\text { Dairy products (16) }\end{array}$ & $\begin{array}{l}\text { Cereals (31) } \\
\text { Soups (28) } \\
\text { Snacks \& sugars (18) }\end{array}$ \\
\hline $\mathrm{Ca}$ & $\begin{array}{l}\text { Dairy products (42) } \\
\text { Cereals }(40)\end{array}$ & $\begin{array}{l}\text { Dairy products (38) } \\
\text { Cereals (36) }\end{array}$ & $\begin{array}{l}\text { Cereals }(29) \\
\text { Dairy products }(26) \\
\text { Snacks \& sugars }(25)\end{array}$ \\
\hline $\mathrm{Fe}$ & $\begin{array}{l}\text { Cereals (66) } \\
\text { Snacks \& sugars (17) }\end{array}$ & $\begin{array}{l}\text { Cereals (49) } \\
\text { Snacks \& sugars (19) }\end{array}$ & $\begin{array}{l}\text { Cereals (44) } \\
\text { Snacks \& sugars (21) } \\
\text { Soup (20) }\end{array}$ \\
\hline $\mathrm{Zn}$ & $\begin{array}{l}\text { Cereals (66) } \\
\text { Dairy products (16) }\end{array}$ & $\begin{array}{l}\text { Cereals (39) } \\
\text { Soups (24) }\end{array}$ & $\begin{array}{l}\text { Soups (39) } \\
\text { Cereals (31) }\end{array}$ \\
\hline Vitamin A & $\begin{array}{l}\text { Cereals (39) } \\
\text { Dairy products (23) } \\
\text { Snacks \& sugars (22) }\end{array}$ & $\begin{array}{l}\text { Meat \& eggs (29) } \\
\text { Cereals }(21) \\
\text { Dairy products }(17) \\
\text { Snacks \& sugars (15) }\end{array}$ & $\begin{array}{l}\text { Meat \& eggs (38) } \\
\text { Snacks \& sugars (16) }\end{array}$ \\
\hline Riboflavin & $\begin{array}{l}\text { Cereals (44) } \\
\text { Dairy products (36) }\end{array}$ & $\begin{array}{l}\text { Cereals }(29) \\
\text { Dairy products (24) }\end{array}$ & $\begin{array}{l}\text { Cereals }(27) \\
\text { Snacks \& sugars }(21)\end{array}$ \\
\hline
\end{tabular}

three age groups. For the two younger age groups, the major sources of energy were cereals, closely followed by snacks and sugars, whereas for the older children, snacks and sugars followed by cereals were the major energy sources. Cereals were also the major source of five nutrients (protein, $\mathrm{Fe}, \mathrm{Zn}$, vitamin A and riboflavin) for the youngest age group, four nutrients (protein, Fe, $\mathrm{Zn}$ and riboflavin) for infants of Grp-2, and four nutrients (protein, $\mathrm{Ca}, \mathrm{Fe}$ and riboflavin) for the children of Grp-3. Dairy products were the major source of $\mathrm{Ca}$ for the two younger age groups, and the secondary source of $\mathrm{Zn}$, vitamin $\mathrm{A}$ and riboflavin for the youngest age group, of riboflavin for children of Grp-2, and of Ca for the oldest age group. Meat and eggs were the major source of only one nutrient (vitamin A) for the two older groups. Snacks and sugars were the secondary source of Fe for all three age groups.

As expected, median intakes of energy and most nutrients (protein, Fe, $\mathrm{Zn}$, thiamin, niacin, fat) were significantly higher $(P<0 \cdot 05)$ for Grp-3 than for Grp-1. Median intakes of energy, protein and riboflavin met the estimated needs ${ }^{(27,30)}$ for all three age groups, but shortfalls existed for $\mathrm{Ca}, \mathrm{Fe}, \mathrm{Zn}$, vitamin $\mathrm{A}$, vitamin $\mathrm{C}$, thiamin and niacin for at least one of the age groups (Table 4). Median intakes of fat were 19,18 and $31 \mathrm{~g} / \mathrm{d}$, providing $30 \%, 26 \%$ and $34 \%$ of energy from fat in complementary foods for Grp-1, Grp-2 and Grp-3, respectively. Median phytate:Zn molar ratios of the complementary foods were very low, ranging from 2 for Grp- 1 to 4 for Grp- 2 and 3 for Grp-3.

In general, median nutrient densities (per $418 \mathrm{~kJ}$ (100 kcal)) of the complementary foods were similar across all three age groups (Table 5), including the den- sities of the three problem micronutrients: Fe, vitamin A and $\mathrm{Zn}$. However, the nutrient density for Ca was markedly higher for the infants of Grp-1 compared with the other two age groups (ANOVA, $P=0 \cdot 018$ ). Median densities for $\mathrm{Fe}$, $\mathrm{Zn}$, Ca, thiamin, niacin, and vitamins $\mathrm{C}$ and $\mathrm{A}$ were all less than $80 \%$ of desired levels for at least two age groups; the greatest deficits were for Fe (assuming low bioavailability) and vitamin $\mathrm{C}$ density for all three age groups, followed by $\mathrm{Zn}$, Ca and vitamin A for two age groups.

\section{Discussion}

To our knowledge, this is the first study to quantify the feeding practices and energy and nutrient intakes from complementary foods for breast-fed children in Mongolia. Our results highlight the poor compliance with the $\mathrm{PAHO} / \mathrm{WHO}$ complementary feeding guidelines and the existence of deficits in the four problem micronutrients from the Mongolian complementary diets, as noted in other disadvantaged countries ${ }^{(4,5,31-35)}$. In contrast, unlike other countries in South/South-East Asia ${ }^{(4,5,31,32)}$, energy intakes from these Mongolian complementary diets appeared adequate, but vitamin $\mathrm{C}$ intakes were low.

\section{Feeding practices}

In Mongolia breast-feeding rates are very high. In the most recent national survey, about $94 \%$ and $75 \%$ of the children were still being breast-fed at 6-11 months and 12-23 months ${ }^{(10)}$, respectively, compared with $96 \%$ and $76 \%$ among the children of our cross-sectional survey ${ }^{(11)}$. However, breast milk may be displaced by the very early 
Table 4 Median (IQR) intakes of energy and selected nutrients from complementary diets for breast-fed Mongolian children, and estimated need and percentage of estimated need ${ }^{\star}$

\begin{tabular}{|c|c|c|c|c|c|c|}
\hline & \multicolumn{2}{|c|}{ Grp-1 (n 26) } & \multicolumn{2}{|c|}{ Grp-2 (n 29) } & \multicolumn{2}{|c|}{ Grp-3 (n 73) } \\
\hline & $\begin{array}{c}\text { Median or estimated } \\
\text { need }\end{array}$ & $\begin{array}{c}\text { IQR or \% of estimated } \\
\text { need }\end{array}$ & $\begin{array}{l}\text { Median or estimated } \\
\text { need }\end{array}$ & $\begin{array}{c}\text { IQR or \% of estimated } \\
\text { need }\end{array}$ & $\begin{array}{l}\text { Median or estimated } \\
\text { need }\end{array}$ & $\begin{array}{c}\text { IQR or } \% \text { of } \\
\text { estimated need }\end{array}$ \\
\hline $\begin{array}{l}\text { Energy (kJ) } \\
\text { Estimated needt }\end{array}$ & $\begin{array}{l}2360 \\
1038\end{array}$ & $\begin{array}{l}1833,2841 \\
227\end{array}$ & $\begin{array}{l}2582 \\
1481\end{array}$ & $\begin{array}{c}1766,3201 \\
174\end{array}$ & $\begin{array}{l}3464 \\
2222\end{array}$ & $\begin{array}{c}3096,3966 \\
156\end{array}$ \\
\hline $\begin{array}{l}\text { Protein }(\mathrm{g}) \\
\quad \text { Estimated need }\end{array}$ & $\begin{array}{r}17 \cdot 4 \\
2 \cdot 0\end{array}$ & $\begin{array}{c}9 \cdot 8,28 \cdot 1 \\
870\end{array}$ & $\begin{array}{r}16 \cdot 8 \\
3 \cdot 1\end{array}$ & $\begin{array}{c}12 \cdot 7,25 \cdot 6 \\
542\end{array}$ & $\begin{array}{r}28 \cdot 2 \\
5 \cdot 1\end{array}$ & $\begin{array}{c}18 \cdot 0,34 \cdot 9 \\
553\end{array}$ \\
\hline $\begin{array}{l}\text { Ca }(\mathrm{mg}) \\
\quad \text { Estimated need }\end{array}$ & $\begin{array}{l}190 \\
111\end{array}$ & $\begin{array}{c}47,337 \\
171\end{array}$ & $\begin{array}{l}136 \\
228\end{array}$ & $\begin{array}{c}58,232 \\
60\end{array}$ & $\begin{array}{l}142 \\
346\end{array}$ & $\begin{array}{c}77,227 \\
41\end{array}$ \\
\hline $\begin{array}{l}\text { Fe }(\mathrm{mg}) \\
\quad \text { Estimated need } \neq\end{array}$ & $\begin{array}{r}1 \cdot 6 \\
18 \cdot 4\end{array}$ & $\begin{array}{c}0.9,2 \cdot 9 \\
9\end{array}$ & $\begin{array}{r}1 \cdot 9 \\
18 \cdot 4\end{array}$ & $\begin{array}{c}1 \cdot 2,2 \cdot 8 \\
10\end{array}$ & $\begin{array}{r}3 \cdot 2 \\
11 \cdot 4\end{array}$ & $\begin{array}{c}2 \cdot 4,4 \cdot 4 \\
28\end{array}$ \\
\hline $\begin{array}{l}\text { Zn (mg) } \\
\quad \text { Estimated need } \$\end{array}$ & $\begin{array}{l}2 \cdot 5 \\
3 \cdot 2 \mathrm{M} \\
4 \cdot 2 \mathrm{~L}\end{array}$ & $\begin{array}{c}1 \cdot 3,3 \cdot 7 \\
78 \\
60\end{array}$ & $\begin{array}{l}2 \cdot 7 \\
3 \cdot 2 \mathrm{M} \\
4 \cdot 2 \mathrm{~L}\end{array}$ & $\begin{array}{c}1 \cdot 8,3 \cdot 1 \\
84 \\
64\end{array}$ & $\begin{array}{l}4 \cdot 0 \\
2 \cdot 4 \mathrm{M} \\
2 \cdot 4 \mathrm{~L}\end{array}$ & $\begin{array}{c}2 \cdot 7,5 \cdot 3 \\
167 \\
167\end{array}$ \\
\hline $\begin{array}{l}\text { Thiamin }(\mathrm{mg}) \\
\text { Estimated need }\end{array}$ & $\begin{array}{l}0 \cdot 2 \\
0 \cdot 2\end{array}$ & $\begin{array}{c}0 \cdot 1,0 \cdot 3 \\
100\end{array}$ & $\begin{array}{l}0 \cdot 2 \\
0 \cdot 2\end{array}$ & $\begin{array}{c}0 \cdot 1,0 \cdot 3 \\
100\end{array}$ & $\begin{array}{l}0 \cdot 3 \\
0 \cdot 4\end{array}$ & $\begin{array}{c}0 \cdot 2,0 \cdot 4 \\
75\end{array}$ \\
\hline $\begin{array}{l}\text { Riboflavin (mg) } \\
\text { Estimated need }\end{array}$ & $\begin{array}{l}0 \cdot 4 \\
0 \cdot 2\end{array}$ & $\begin{array}{c}0 \cdot 2,0 \cdot 6 \\
200\end{array}$ & $\begin{array}{l}0 \cdot 4 \\
0 \cdot 2\end{array}$ & $\begin{array}{c}0 \cdot 3,0 \cdot 7 \\
200\end{array}$ & $\begin{array}{l}0 \cdot 4 \\
0 \cdot 3\end{array}$ & $\begin{array}{c}0 \cdot 3,0 \cdot 6 \\
133\end{array}$ \\
\hline $\begin{array}{l}\text { Niacin }(\mathrm{mg}) \\
\quad \text { Estimated need }\end{array}$ & $\begin{array}{l}2 \cdot 6 \\
3 \cdot 0\end{array}$ & $\begin{array}{c}1 \cdot 5,5 \cdot 2 \\
87\end{array}$ & $\begin{array}{l}3 \cdot 8 \\
3 \cdot 1\end{array}$ & $\begin{array}{c}1 \cdot 8,4 \cdot 6 \\
123\end{array}$ & $\begin{array}{l}4 \cdot 8 \\
5 \cdot 2\end{array}$ & $\begin{array}{c}3 \cdot 5,6 \cdot 6 \\
92\end{array}$ \\
\hline $\begin{array}{l}\text { Ascorbic acid (mg) } \\
\text { Estimated need }\end{array}$ & $\begin{array}{l}2 \cdot 1 \\
3 \cdot 0\end{array}$ & $\begin{array}{c}1 \cdot 0,3 \cdot 4 \\
70\end{array}$ & $\begin{array}{l}1 \cdot 6 \\
5 \cdot 4\end{array}$ & $\begin{array}{c}0 \cdot 7,5 \cdot 3 \\
30\end{array}$ & $\begin{array}{l}2 \cdot 7 \\
8 \cdot 0\end{array}$ & $\begin{array}{c}1 \cdot 3,5 \cdot 7 \\
34\end{array}$ \\
\hline $\begin{array}{l}\text { Vitamin } A \text { ( } \mu \mathrm{g} R E) \\
\text { Estimated need }\end{array}$ & $\begin{array}{l}78 \cdot 0 \\
63 \cdot 0\end{array}$ & $\begin{array}{c}22 \cdot 5,109 \cdot 4 \\
124\end{array}$ & $\begin{array}{l}61 \cdot 4 \\
92 \cdot 0\end{array}$ & $\begin{array}{c}22 \cdot 8,108 \cdot 4 \\
67\end{array}$ & $\begin{array}{r}58 \cdot 3 \\
125 \cdot 0\end{array}$ & $\begin{array}{c}20 \cdot 7,136 \cdot 0 \\
47\end{array}$ \\
\hline $\begin{array}{l}\text { Fat }(\mathrm{g}) \\
\% \text { energy from fatll } \\
\text { Recommended \% } \\
\text { energy from fat }\end{array}$ & $\begin{array}{c}19 \\
30 \\
0 \Psi ; 34^{\star *}(\mathrm{MB})\end{array}$ & 12,28 & $\begin{array}{c}18 \\
26 \\
5 \uparrow ; 38^{* \star}(\mathrm{MB})\end{array}$ & 13,26 & $\begin{array}{c}31 \\
34 \\
17 \mp ; 42^{\star \star}(\mathrm{MB})\end{array}$ & 19,42 \\
\hline
\end{tabular}


Table 5 Median (IQR) nutrient densities* of the complementary diets of breast-fed Mongolian children, and desired density and percentage of desired density

\begin{tabular}{|c|c|c|c|c|c|c|}
\hline & \multicolumn{2}{|c|}{ Grp-1 (n 26) } & \multicolumn{2}{|c|}{ Grp-2 (n 29) } & \multicolumn{2}{|c|}{ Grp-3 (n 73) } \\
\hline & $\begin{array}{l}\text { Median or desired } \\
\text { density }\end{array}$ & $\begin{array}{c}\text { IQR or \% of desired } \\
\text { density }\end{array}$ & $\begin{array}{l}\text { Median or desired } \\
\text { density }\end{array}$ & $\begin{array}{c}\text { IQR or \% of desired } \\
\text { density }\end{array}$ & $\begin{array}{l}\text { Median or desired } \\
\text { density }\end{array}$ & $\begin{array}{c}\text { IQR or \% of desired } \\
\text { density }\end{array}$ \\
\hline $\begin{array}{l}\text { Protein }(\mathrm{g} / 418 \mathrm{~kJ}) \\
\text { Desired density } †\end{array}$ & $\begin{array}{l}3 \cdot 0 \\
0.8\end{array}$ & $\begin{array}{c}2 \cdot 8,4 \cdot 5 \\
375\end{array}$ & $\begin{array}{l}3.0 \\
0.9\end{array}$ & $\begin{array}{c}2 \cdot 5,3 \cdot 6 \\
333\end{array}$ & $\begin{array}{l}3 \cdot 2 \\
1 \cdot 0\end{array}$ & $\begin{array}{c}2 \cdot 7,3 \cdot 7 \\
320\end{array}$ \\
\hline $\begin{array}{l}\mathrm{Ca}(\mathrm{mg} / 418 \mathrm{~kJ}) \\
\text { Desired density }\end{array}$ & $\begin{array}{l}44 \cdot 4 \\
45\end{array}$ & $\begin{array}{c}20 \cdot 0,59 \cdot 1 \\
99\end{array}$ & $\begin{array}{l}24 \cdot 7 \\
64\end{array}$ & $\begin{array}{c}13 \cdot 3,32 \cdot 5 \\
39\end{array}$ & $\begin{array}{l}16 \cdot 4 \\
65\end{array}$ & $\begin{array}{c}11 \cdot 3,22 \cdot 1 \\
25\end{array}$ \\
\hline $\begin{array}{l}\mathrm{Fe}(\mathrm{mg} / 418 \mathrm{~kJ}) \\
\text { Desired density }\end{array}$ & $\begin{array}{l}0 \cdot 3 \\
7 \cdot 4\end{array}$ & $\begin{array}{c}0 \cdot 2,0 \cdot 4 \\
4\end{array}$ & $\begin{array}{l}0 \cdot 3 \\
5 \cdot 2\end{array}$ & $\begin{array}{c}0 \cdot 3,0 \cdot 5 \\
6\end{array}$ & $\begin{array}{l}0 \cdot 4 \\
2 \cdot 2\end{array}$ & $\begin{array}{c}0 \cdot 3,0 \cdot 5 \\
18\end{array}$ \\
\hline $\begin{array}{l}\text { Zn (mg/418 kJ) } \\
\text { Desired density§ }\end{array}$ & $\begin{array}{l}0.5 \\
1.38 \mathrm{M} \\
1.82 \mathrm{~L}\end{array}$ & $\begin{array}{c}0 \cdot 3,0 \cdot 7 \\
36 \\
27\end{array}$ & $\begin{array}{l}0.4 \\
0.90 \mathrm{M} \\
1 \cdot 19 \mathrm{~L}\end{array}$ & $\begin{array}{c}0 \cdot 3,0 \cdot 5 \\
44 \\
34\end{array}$ & $\begin{array}{l}0.5 \\
0.45 \mathrm{M} \\
0.45 \mathrm{~L}\end{array}$ & $\begin{array}{c}0 \cdot 3,0 \cdot 6 \\
111 \\
111\end{array}$ \\
\hline $\begin{array}{l}\text { Thiamin (mg/418 kJ) } \\
\text { Desired density }\end{array}$ & $\begin{array}{l}0.03 \\
0.08\end{array}$ & $\begin{array}{c}0 \cdot 03,0 \cdot 04 \\
38\end{array}$ & $\begin{array}{l}0.03 \\
0.06\end{array}$ & $\begin{array}{c}0 \cdot 03,0 \cdot 04 \\
50\end{array}$ & $\begin{array}{l}0.04 \\
0.08\end{array}$ & $\begin{array}{c}0 \cdot 03,0 \cdot 05 \\
50\end{array}$ \\
\hline $\begin{array}{l}\text { Riboflavin (mg/418 kJ) } \\
\text { Desired density }\end{array}$ & $\begin{array}{l}0.09 \\
0.08\end{array}$ & $\begin{array}{c}0 \cdot 05,0 \cdot 10 \\
113\end{array}$ & $\begin{array}{l}0.06 \\
0.06\end{array}$ & $\begin{array}{c}0.04,0.09 \\
100\end{array}$ & $\begin{array}{l}0.05 \\
0.06\end{array}$ & $\begin{array}{c}0.04,0.06 \\
83\end{array}$ \\
\hline $\begin{array}{l}\text { Niacin }(\mathrm{mg} / 418 \mathrm{~kJ}) \\
\text { Desired density }\end{array}$ & $\begin{array}{l}0 \cdot 6 \\
1 \cdot 2\end{array}$ & $\begin{array}{c}0 \cdot 4,0 \cdot 7 \\
50\end{array}$ & $\begin{array}{l}0.6 \\
0.9\end{array}$ & $\begin{array}{c}0 \cdot 3,0 \cdot 7 \\
67\end{array}$ & $\begin{array}{l}0 \cdot 6 \\
1 \cdot 0\end{array}$ & $\begin{array}{c}0 \cdot 5,0 \cdot 8 \\
60\end{array}$ \\
\hline $\begin{array}{l}\text { Ascorbic acid (mg/418 kJ) } \\
\text { Desired density }\end{array}$ & $\begin{array}{l}0 \cdot 3 \\
1 \cdot 2\end{array}$ & $\begin{array}{c}0 \cdot 2,0 \cdot 6 \\
25\end{array}$ & $\begin{array}{l}0.3 \\
1.5\end{array}$ & $\begin{array}{c}0 \cdot 1,0 \cdot 5 \\
20\end{array}$ & $\begin{array}{l}0.4 \\
1.5\end{array}$ & $\begin{array}{c}0 \cdot 2,0 \cdot 6 \\
27\end{array}$ \\
\hline $\begin{array}{l}\text { Vitamin A ( } \mu \mathrm{g} R E / 418 \mathrm{~kJ} \text { ) } \\
\text { Desired density }\end{array}$ & $\begin{array}{l}13 \cdot 9 \\
25\end{array}$ & $\begin{array}{c}5 \cdot 9,20 \cdot 6 \\
56\end{array}$ & $\begin{array}{l}9 \cdot 2 \\
26\end{array}$ & $\begin{array}{c}4 \cdot 2,15 \cdot 6 \\
35\end{array}$ & $\begin{array}{l}7 \cdot 7 \\
24\end{array}$ & $\begin{array}{c}2 \cdot 8,12 \cdot 7 \\
32\end{array}$ \\
\hline
\end{tabular}

IQR, interquartile range; RE, retinol equivalents.

*Nutrient density $=$ amount/ $418 \mathrm{~kJ}(100 \mathrm{kcal})$.

tDesired nutrient densities assuming average breast milk intake and nutrient content, as determined by $\mathrm{WHO}^{(3)}$. Desired levels were calculated by dividing the estimated energy needs by the estimated needs for energy intake for each age group.

¥Percentage desired Fe density assuming low bioavailability.

§Based on International Zinc Nutrition Consultative Group Recommended Dietary Allowance for $\mathrm{Zn}^{(28)}$ assuming a refined (M) and unrefined cereal-based (L) diet. 
introduction of complementary foods, as noted here and by others ${ }^{(5,13,36,37)}$. The most recent $\mathrm{WHO}^{(38)}$ recommendation is for exclusive breast feeding up to 6 months of age. The first complementary foods introduced in the current study were wheat-based porridges with very low energy densities $(1.42 \mathrm{~kJ} / \mathrm{g}(0.34 \mathrm{kcal} / \mathrm{g})$ for semolina and $1.76 \mathrm{~kJ} / \mathrm{g}(0.42 \mathrm{kcal} / \mathrm{g})$ for bantan $)^{(39)}$, which were rarely enriched with cellular animal foods, darkgreen vegetables or yellow-orange fruits, as emphasized by the very small proportion of children consuming any Fe- or vitamin-A-rich foods (Table 2). Hence, very few of our Mongolian infants or children received complementary foods containing the minimum number of food groups per day, a shortfall that tended to be more marked among the Grp- 2 and Grp-3 children than among the infants aged 6 to 8 months. This trend may have arisen because of the failure to practise active feeding, particularly as caregivers tend to leave children to feed themselves once they start to eat independently ${ }^{(13)}$. Consequently, dietary diversity, based on the mean number of food groups consumed ${ }^{(18)}$, was much lower for these Mongolian children than has been reported in the Demographic and Health Surveys of young children from other countries in South/South-East Asia and Central Asia ${ }^{(40)}$.

The Mongolian children were also not receiving the recommended number of feedings per day. Instead, a relatively large proportion of the energy was contributed by non-nutritious snacks and sweets (Table 3), as reported for Cambodian children ${ }^{(5)}$. The Mongolian snacks were mainly doughnuts and biscuits, whereas in Cambodia, they were crisps, biscuits and sponge cake; all energy-dense but with a very low micronutrient density. This is of concern because frequent consumption of such energy-dense snacks by young breast-fed children has the potential to displace breast milk ${ }^{(4,41)}$.

The consumption of tea was also a frequent practice among children in both Mongolia and Cambodia ${ }^{(5)}$. Polyphenols in tea are likely to have a marked adverse effect on non-haem Fe absorption, particularly in Mongolian complementary diets ${ }^{(42)}$ because of their low content of ascorbic acid and cellular animal protein, two enhancers of non-haem Fe absorption ${ }^{(43)}$. On average, $\leq 1 \%$ of the energy intake from complementary foods was from meat and eggs or fruits and vegetables, with many children not consuming these foods.

\section{Adequacy of energy and nutrient intakes}

In view of the poor feeding practices discussed above, it is not surprising that large deficits in the four problem micronutrients ${ }^{(3)}-\mathrm{Ca}, \mathrm{Fe}, \mathrm{Zn}$ and vitamin $\mathrm{A}$, as well as vitamin C were a notable feature of these Mongolian complementary diets for at least two age groups (Tables 4 and 5) and irrespective of setting. These findings parallel those for young breast-fed children living in other disadvantaged countries in South/South-East Asia ${ }^{(4,5,31,32)}$ and sub-Saharan $\mathrm{Africa}^{(33-35)}$, where cereal-based complementary diets containing little micronutrient-dense cellular animal foods, dark-green vegetables or yellow-orange fruits predominate.

It is of interest that the deficits in micronutrient intakes occurred even though the median energy intakes derived from complementary foods and energy-dense snacks for each age group exceeded our estimated energy needs (Table 4), and each was accompanied by a positive mean WLZ (Table 1). Nevertheless, it is possible that our calculated energy needs from complementary foods alone were underestimated, especially for the breast-fed infants aged 6 to 8 months, because we used data for breast milk intakes compiled from other low-income countries ${ }^{(3)}$ rather than from direct measurements of breast milk volume for Mongolian children. Indeed, elsewhere in South/South-East Asia $^{(4,531,32)}$, marked deficits in intakes of energy and micronutrients from complementary foods, accompanied by negative WLZ indicative of wasting, have been reported.

Despite the positive mean WLZ for each age group, the mean LAZ for the oldest group (i.e. aged 12 to 23 months) was negative (Table 1). Such a trend is well recognized in children of this age from longitudinal studies both in Asia $^{(44)}$ and sub-Saharan Africa ${ }^{(45)}$, and reflects a progressive deterioration in their nutritional status as breast milk becomes increasingly replaced with the traditional complementary foods of low micronutrient quality.

Calculations (not shown) indicate that even if the Mongolian caregivers fed the wheat-based complementary foods for the recommended minimum number of times per day, intakes of the four problem micronutrients and vitamin $\mathrm{C}$ would still be suboptimal because of the low micronutrient density of these porridges. Similar findings have been reported elsewhere in the region ${ }^{(4,5,32)}$.

Detailed biochemical data ${ }^{(11)}$ on these same children, collected at the same time as the current dietary data, corroborate the evidence presented here that intakes from complementary foods of three of the problem micronutrients - Fe, $\mathrm{Zn}$ and vitamin $\mathrm{A}$ - are inadequate. Indeed, of these breast-fed children, $24 \%$ had Fe-deficiency anaemia while $77 \%$ and $40 \%$ had low serum $\mathrm{Zn}$ and retinol concentrations, respectively. No biochemical assessment of $\mathrm{Ca}$ or vitamin $\mathrm{C}$ status was undertaken.

The discrepancy between the high prevalence of low serum $\mathrm{Zn}$ concentrations and the relatively modest levels of stunting among these breast-fed Mongolian children has been discussed earlier ${ }^{(11)}$. An unusual feature of these complementary diets is the frequent consumption of cow's milk products, some of which are fermented. As a result, the $\mathrm{Ca}$ intakes and densities of the complementary diets, especially for Grp-1, were markedly higher than many reported elsewhere ${ }^{(4,33-36)}$. Significantly, there is some evidence that cow's milk has a positive effect on linear growth ${ }^{(46)}$, associated, at least in part, with the stimulating effect of cow's milk on insulin-like growth factors (IGF-I). Products prepared from fermented milk, such as yoghurt, also contain growth-promoting factors ${ }^{(47)}$. Hence, perhaps the increases in circulating levels of IGF-I stimulated by cow's milk and 
fermented yoghurt were sufficient to overcome, at least in part, the reduction in IGF-I levels induced by suboptimal $\mathrm{Zn}$ status in these Mongolian children ${ }^{(48)}$.

We recognize that our results are not based on a nationally representative sample of breast-fed Mongolian children, and that the number of children in each age group was small. Hence caution must be used when interpreting our results. Nevertheless, the sampling in each of the provincial capitals and in the four districts of Ulaanbaatar was random, and several nutritional status variables for these Mongolian children, including the overall prevalence of stunting, anaemia, use of vitamin A supplements and breastfeeding practices, were comparable to those reported in the most recent national survey ${ }^{(10)}$ and in a smaller study ${ }^{(49)}$ in Mongolia. Other methodological limitations include the collection of data on exclusive breast-feeding based on selfreports by the mothers during the recalls rather than direct observations; our estimate of breast milk volume based on data compiled from low-income countries other than Mongolia, and not by direct measurements; and the use of a single $24 \mathrm{~h}$ recall to assess intakes of complementary foods. As a result, we could not calculate the usual nutrient intakes derived from both breast milk and complementary food for each child, and thus could not apply the estimated average requirement cut-point method to compare the prevalence of inadequate intakes for each age group ${ }^{(50)}$. Instead, we compared the median intakes from complementary food alone for the three age groups with the corresponding WHO estimated needs ${ }^{(3,29)}$.

\section{Conclusions and recommendations}

The present study has highlighted the poor dietary quality of the complementary diets of breast-fed children in Mongolia. With the exception of vitamin A, the shortfalls in $\mathrm{Ca}, \mathrm{Fe}, \mathrm{Zn}$ and probably vitamin $C$ cannot be rectified by improving the levels in breast milk, because they are independent of maternal nutritional status ${ }^{(3)}$. Enhancing maternal Fe status could, however, have a positive impact on the Fe status of these children through its effect on placental transfer ${ }^{51,52)}$. Clearly, efforts should be made to educate caregivers to enhance the dietary quality of the complementary foods fed to children by enriching the cereal-based porridges with affordable cellular animal foods and vitamin-C-rich seasonal fruits, and restricting the intake of tea and inappropriate snacks of low micronutrient density. Our findings also emphasize the importance of educating the health-care providers in these settings to ensure that they are familiar with the PAHO/WHO (2003) ${ }^{(1)}$ guiding principles for complementary feeding practices and behaviours.

\section{Acknowledgements}

Sources of funding: This research was funded by World Vision Mongolia, UNICEF Mongolia and WHO Mongolia, and supported by the University of Otago. Conflict of interest: The authors have no conflict of interest. Contributions of the authors: R.L. initiated the study, provided overall supervision in Ulaanbaatar, and created the Mongolian nutrient database; Ts.E. and J.B. provided oversight for the survey; N.B., D.E., U.T. and S.T. supervised the data collection; K.B. analysed critical complementary foods for Fe, Zn and phytate; R.S.G. supervised the calculation of the nutrient intakes and data analysis, and wrote the manuscript after a draft by R.L. Acknowledgments: The authors acknowledge the invaluable contributions of the assistant researchers from the Nutrition Research Centre (NRC), Public Health Institute, Ulaanbaartar, Mongolia and the caregivers of these children.

\section{References}

1. Pan American Health Organization/World Health Organization (2003) Guiding Principles for Complementary Feeding of the Breastfed Child. Washington, DC: Division of Health Promotion and Protection, Food and Nutrition Program.

2. Gibson RS, Ferguson EL \& Lehrfeld J (1997) Complementary foods for infant feeding in developing countries: their nutrient adequacy and improvement. Eur J Clin Nutr 52, 764-770

3. World Health Organization (1998) Complementary Feeding of Young Children in Developing Countries: A Review of Current Scientific Knowledge. Geneva: WHO.

4. Kimmons JE, Dewey KG, Haque E et al. (2005) Low nutrient intakes among infants in rural Bangladesh are attributable to low intake and micronutrient density of complementary foods. J Nutr 135, 444-451.

5. Anderson VP, Cornwall J, Jack S et al. (2008) Intakes from non-breastmilk foods for stunted toddlers living in poor urban villages of Phnom Penh, Cambodia are inadequate. Matern Child Nutr 4, 146-159.

6. Gibson RS, Perlas LA \& Hotz C (2006) Improving the bioavailability of nutrients in plant foods at the household level. Proc Nutr Soc 65, 160-168.

7. Marquis GS, Habicht J-P, Lanata CF et al. (1997) Breast milk or animal-product foods improve linear growth of Peruvian toddlers consuming marginal diets. Am J Clin Nutr 66, 1102-1109.

8. Guldan GS, Fan H, Ma X et al. (2000) Culturally appropriate nutrition education improves infant feeding and growth in rural Sichuan, China. J Nutr 130, 1204-1211.

9. Penny ME, Creed-Kanashiro HM, Robert RC et al. (2005) Effectiveness of an educational intervention delivered through health services to improve nutrition in young children: a cluster-randomised controlled trial. Lancet 365, $1863-1872$.

10. Nutrition Research Centre, Mongolian Public Health Institute/UNICEF (2006) Nutritional Status of Mongolian Children and Women 2004 - 3rd National Nutrition Survey Report. Ulaanbaatar: UNICEF.

11. Lander RL, Enkhjargal T, Batjargal J et al. (2008) Multiple micronutrient deficiencies persist during early childhood in Mongolia. Asia Pac J Clin Nutr 17, 429-440.

12. Nutrition Research Centre, Mongolian Public Health Institute/UNICEF (2002) Nutrition Status of Population of Mongolia 2000 - 2nd National Nutrition Survey Report. Ulaanbaatar: UNICEF.

13. Batjargal J, Balgimaa B, Ganzorig D et al. (2002) Care Practices for Young Children in Mongolia. A Qualitative 
Survey Report. Ulaanbaatar: Mongolian Ministry of Health/ UNICEF.

14. Blössner M, Siyam A, Borghi E et al. (2007) WHO Anthro for Personal Computers: Software for Assessing Growth and Development of the World's Children. Geneva: WHO.

15. World Health Organization (1995) Physical Status: The Use and Interpretation of Anthropometry. Report of a WHO Expert Committee. Geneva: WHO.

16. Gibson RS \& Ferguson EL (1999) An Interactive 24- $h r$ Recall for Assessing the Adequacy of Iron and Zinc Intakes in Developing Countries. Washington, DC: International Life Sciences Institute Publishers.

17. Arimond M \& Ruel MT (2003) Generating Indicators of Appropriate Feeding of Children Through 23 Months from the KPC 2000+. Washington, DC: Food and Nutrition Technical Assistance Project.

18. Arimond M \& Ruel MT (2004) Dietary diversity is associated with child nutritional status: evidence from 11 demographic and health surveys. J Nutr 134, 2579-2585.

19. US Department of Agriculture (2003) National Nutrient Database for Standard Reference. Release 16. Washington, DC: Nutrient Data Laboratory, US Government Printing Office; available at http://www.nal.usda.gov/fnic/foodcomp

20. Institute of Nutrition, Mahidol University (2002) Food Composition Database for INMUCAL Program. Salaya, Thailand: INMU.

21. Siong TE, Noor MI, Adudin MN et al. (1997) Nutrient Composition of Malaysia Foods, 4th ed. Kuala Lumpur: Institute for Medical Research.

22. Food and Nutrition Research Institute (1997) The Philippine Food Composition Tables. Manila: Food and Nutrition Research Institute, Department of Science and Technology.

23. Bunch S \& Murphy SP (1997) User's Guide to the Operation of the World Food Dietary Assessment Program. Berkeley, CA: Office of Technology Licensing, University of California.

24. Krittaphol W, Bailey KB, Pongcharoen T et al. (2007) Low zinc, iron, and calcium intakes of northeast Thai school children consuming glutinous rice-based diets are not exacerbated by high phytate. Int J Food Sci Nutr 57, 520-528.

25. US Department of Agriculture (2003) USDA Table of Nutrient Retention Factors, Release 5. Washington, DC: US Government Printing Office; available at http:// www.nal.usda.gov/fnic/foodcomp

26. Banjong O, Viriyapanich T \& Chittchang U (2001) Food Quantity Conversion Handbook. Salaya, Thailand: Institute of Nutrition, Mahidol University.

27. World Health Organization/Food and Agriculture Organization of the United Nations (2004) Vitamin and Mineral Requirements in Human Nutrition, 2nd ed. Geneva: WHO.

28. Hotz C \& Brown KM (2004) Assessment of the risk of zinc deficiency in populations and options for its control. Food Nutr Bull 25, 1 Suppl. 2, S99-S199.

29. Dewey K \& Brown K (2003) Update on technical issues concerning complementary feeding of young children in developing countries and implications for intervention programs. Food Nutr Bull 24, 5-28.

30. Food and Agriculture Organization of the United Nations/ World Health Organization/United Nations University (2004) Human Energy Requirements. Food and Nutrition Technical Report Series no. 1. Rome: FAO/WHO/UNU.

31. Brown KH, Black RE, Becker S et al. (1982) Consumption of foods and nutrients by weanlings in rural Bangladesh. Am J Clin Nutr 36, 878-889.

32. Perlas LA, Gibson RS \& Adair LS (2004) Macronutrient and selected vitamin intakes from complementary foods of infants and toddlers from Cebu, Philippines. Int J Food Sci Nutr 55, 1-15.
33. Hautvast JLA, van der Heijden LJM, Luneta AK et al. (1999) Food consumption of young stunted and non-stunted children in rural Zambia. Eur J Clin Nutr 53, 50-59.

34. Hotz C \& Gibson RS (2001) Complementary feeding practices and dietary intakes from complementary foods amongst weanlings in rural Malawi. Eur J Clin Nutr 55, 841-849.

35. Gibson RS, Abebe Y, Hambidge KM et al. (2009) Inadequate feeding practices and impaired growth among children from subsistence farming households in Sidama, southern Ethiopia. Matern Child Nutr 5, 260-275.

36. Jackson DA, Imong SM, Wongsawasdii L et al. (1991) Weaning practices and breast-feeding duration in northern Thailand. Br J Nutr 67, 149-164.

37. Villavieja GM, Cerdeňa CM, Laňa RD et al. (1998) Assessing Dietary Status of 0-59 Month-Old Filipino Children, Pregnant and Lactating Women. Manila: Food and Nutrition Research Institute.

38. World Health Organization (2002) The Optimal Duration of Exclusive Breastfeeding. Report of an Expert Consultation. Geneva: WHO.

39. Brown KH (1997) Complementary feeding in developing countries: factors affecting energy intake. Proc Nutr Soc 56, 139-148.

40. Mukuria AG, Kothari MT \& Abderrahim N (2006) Infant and Young Child Feeding Update. Calverton, MD: ORC Macro.

41. Drewett R, Amatayakul K, Wongsawasdii L et al. (1993) Nursing frequency and the energy intake from breast milk and supplementary food in a rural Thai population: a longitudinal study. Eur J Clin Nutr 47, 880-891.

42. Mennen LI, Walker R, Bennetau-Pelissero C et al. (2005) Risks and safety of polyphenol consumption. Am J Clin Nutr 81, 1 Suppl., 326S-329S.

43. Hallberg L (1981) Bioavailability of dietary iron in man. Annu Rev Nutr 1, 123-147.

44. Adair LS \& Guilkey DK (1997) Age-specific determinants of stunting in Filipino children. J Nutr 127, 314-320.

45. Hautvast JLA, Tolboom JJM, Kafwembe EM et al. (2000) Severe linear growth retardation in rural Zambian children: the influence of biological variables. Am J Clin Nutr 71, $550-559$.

46. Hoope C, Mǿlgaard C \& Michaelsen KF (2006) Cow's milk and linear growth in industrialized and developing countries. Annu Rev Nutr 26, 131-173.

47. Brunser O, Gotteland S \& Cruchet S (2007) Functional fermented milk products. In: Issues in Complementary Feeding. Nestlé Nutrition Workshop Series Pediatric Program, vol. 60, pp. 235-250 [C Agostoni and O Brunser, editors]. Basel: Karger AG.

48. Ninh NX, Thissen JP, Collette L et al. (1996) Zinc supplementation increases growth and circulating insulinlike growth factor I (1GF-I) in growth-retarded Vietnamese children. Am J Clin Nutr 63, 514-519.

49. World Vision Mongolia (2005) Effectiveness of Home-based Fortification with Sprinkles in an Integrated Nutrition Program to Address Rickets and Anemia. Ulaanbaatar: WV Mongolia.

50. Barr SI, Murphy SP \& Poos MI (2002) Interpreting and using the Dietary Reference Intakes in dietary assessment of individuals and groups. J Am Diet Assoc 102, 780-788.

51. Milman N, Ibsen KK \& Christensen JM (1987) Serum ferritin and iron status in mothers and newborn infants. Acta Obstet Gynecol Scand 66, 205-211.

52. McArdle HJ, Danzeisen R, Fosset C et al. (2003) The role of the placenta in iron transfer from mother to fetus and the relationship between iron status and fetal outcome. Biometals 16, 161-167. 